Gut, 1977, 18, 121-127

\title{
Lowering of fasting and food stimulated serum immunoreactive gastric inhibitory polypeptide (GIP) by glucagon
}

\author{
R. EBERT, R. ARNOLD, AND W. CREUTZFELDT ${ }^{1}$ \\ From the Division of Gastroenterology and Metabolism, Department of Medicine, \\ University of Göttingen, $W$. Germany
}

SUMMARY The effect of intravenous glucagon infusion on serum levels of immunoreactive GIP (IR-GIP), insulin (IRI), gastrin (IRG), and on blood glucose has been investigated in six healthy volunteers in the fasting state and during ingestion of a mixed standard meal. Glucagon $(500 \mathrm{ng} / \mathrm{kg} / \mathrm{min}$ ) lowered significantly serum levels of IR-GIP and IRG below the fasting values and increased the levels of IRI and blood glucose. Glucagon $(50 \mathrm{ng} / \mathrm{kg} / \mathrm{min})$ infused $30 \mathrm{minutes}$ before and continued 90 minutes after ingestion of a test meal abolished the IR-GIP response, suppressed significantly the IRG response, and left the IRI response unchanged. The same glucagon dose infused 60 minutes after ingestion of the test meal decreased significantly the raised levels of IR-GIP and IRG to fasting levels without changing IRI values. It is concluded that exogenous glucagon inhibits GIP release at the level of the GIP-producing cells.

Gastric inhibitory polypeptide (GIP) isolated from the small intestine is an inhibitor of basal and stimulated gastric secretion and potentiates the glucose induced insulin secretion (Brown et al., 1975). GIP is released after ingestion of glucose (Cataland et al., 1974; Brown et al., 1975), fat (Brown et al., 1975; Falko et al., 1975) and amino acids (Thomas et al., 1976). However, little is known about other factors influencing GIP release. The existence of such factors is of interest because an altered response to ingested glucose or a test meal has been described in different gastrointestinal and metabolic disorders (Bloom, 1975; Brown et al., 1975; Crockett et al., 1975; Botha et al., 1976; Ebert et al., 1976a, b). A feedback inhibition of GIP release by insulin has been suggested (Brown et al., 1975; Cleator and Gourlay, 1975; Crockett et al., 1976) and the rate of absorption as regulator of GIP release discussed (Brown et al., 1975; Creutzfeldt et al., 1976; Ebert et al., 1976a).

Interactions of gastrointestinal hormones have been previously described. Secretin (Hansky et al., 1971; Thompson et al., 1972) and glucagon (Becker et al., 1973; Hansky et al., 1973) are able to lower fasting and food stimulated serum gastrin response

\footnotetext{
'Address for correspondence: Professor Dr. med. W. Creutzfeldt, Medizinische Universitätsklinik, Humboldtallee 1, D-3400 Güttingen, W. Germany.

Received for publication 29 December 1976
}

in healthy subjects and patients with duodenal ulcer. Therefore, the effect of glucagon infusions on the serum levels of immunoreactive GIP (IR-GIP), gastrin (IR-G) and insulin (IRI) was investigated in healthy subjects. It will be shown that glucagon infusion reduces basal IR-GIP levels and inhibits the IR-GIP response to a test meal.

\section{Methods}

\section{SUBJECTS}

The studies were performed in six healthy volunteers, two females and four males with a mean age of 25 years (range from 19-32 years). These subjects were within $10 \%$ of their ideal body weight (mean weight $68.6 \mathrm{~kg}$ ) and had a normal glucose tolerance. Informed consent was obtained from all subjects.

\section{TEST PROCEDURE}

After an overnight fast and at least a 45 minute rest in the supine position an indwelling cannula was inserted into the antecubital vein of one arm for blood sampling and another cannula was inserted into the opposite arm for the infusion of glucagon. Both cannulas were kept patent by slow infusion of saline. The effect of glucagon on fasting and meal stimulated hormone levels was investigated. Three basal blood samples were collected, after which the intravenous infusion of glucagon was started. For 
30 minutes glucagon was administered at a concentration of $50 \mathrm{ng} / \mathrm{kg} / \mathrm{min}$, the concentration was then raised to $500 \mathrm{ng} / \mathrm{kg} / \mathrm{min}$ during the next 30 minutes. In the other experiments, after taking basal samples, $550 \mathrm{ml}$ of a mixed liquid test meal was ingested within 10 minutes. The test meal consisted of $400 \mathrm{ml}$ Dextro $^{(\mathrm{R})}$ OGT, containing $18 \mathrm{~g}$ glucose, $14 \mathrm{~g}$ maltose, $12 \mathrm{~g}$ maltotriose, $56 \mathrm{~g}$ oligosaccharides, corresponding to $100 \mathrm{~g}$ rapidly absorbable glucose (Pomps GmbH, Heilbronn), $100 \mathrm{ml}$ cream (contain-

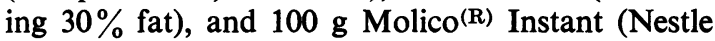
$\mathrm{GmbH}$, Lindau), containing $36 \mathrm{~g}$ protein and $52 \mathrm{~g}$ lactose. This test meal contained 1031 calories. The osmolarity was $1280 \mathrm{mosmol} / \mathrm{l}$.

Blood samples were taken at 15 minute intervals one hour before and three hours after ingestion of the test meal. The samples were immediately placed on ice and centrifuged at $4^{\circ} \mathrm{C}$. Five aliquots of each serum sample were frozen and stored at $-20^{\circ} \mathrm{C}$ until assayed.

Glucagon (Glucagon, Eli Lilly Co, Gießen) for infusion was prepared immediately before use (approximately $10 \mu \mathrm{g} / \mathrm{ml}$ concentration) in physiological saline containing human serum albumin (Behringwerke AG, Marburg/Lahn) $2 \mathrm{~g} / 100 \mathrm{ml}$, and a small amount of aprotinin (Trasylol, Bayer AG, Leverkusen) $50 \mathrm{KIU} / \mathrm{ml}$, in order to prevent absorption and proteolytic breakdown of glucagon within the infusion apparatus. The glucagon infusion was started in one series of experiments 30 minutes before ingestion of the test meal and continued till 90 minutes after ingestion at an infusion rate of $50 \mathrm{ng} / \mathrm{kg} / \mathrm{min}$ (protocol 1). In another series of experiments glucagon was infused from 60 minutes to 150 minutes after ingestion of the test meal at the same infusion rate (protocol 2). All subjects served as their own controls-that is, the test was repeated without glucagon within six to 14 days.

\section{LABORATORY ANALYSES}

Serum glucose was measured in duplicate on each sample by the glucose oxidase method after separating the serum. Serum calcium was determined complexometrically using the autoanalyser SMA 6/60.

IRI, IRG, and IR-GIP were determined in duplicate on each sample within four weeks after the test. Serum IRI was determined using human insulin as a standard (Melani et al., 1965). Serum IRG was estimated as described previously (Mayer et al., 1974) using antiserum 118/2/3. Serum IR-GIP was measured as described elsewhere (Creutzfeldt $e t$ al., 1976) using the technique of Kuzio et al. (1974) with the antibody Van No. 8. Minor modifications were introduced improving the sensitivity of the assay. The amount of GIP for the labelling procedure was reduced from $6 \mu \mathrm{g}$ to $0.5 \mu \mathrm{g}$ per label. At the day of use a batch of $0.5 \mathrm{~g}$ Dowex $\left(\mathrm{Cl}^{-}, 50-100 \mathrm{mesh}\right)$ was added to a portion of the label, mixed and centrifuged after five minutes. By this procedure free iodine was removed and thereby the non-specific binding reduced to about $4-6 \%$. About $15 \%$ displacement of bound GIP was achieved by $6 \mathrm{pg}, 50 \%$ displacement by $82 \mathrm{pg}$ GIP (mean of 48 assays). The lower limit of sensitivity varied from assay to assay ranging from $3 \mathrm{pg}$ to $10 \mathrm{pg}$. As final serum dilution in our assays is $1: 10$, the actual sensitivity for practical determination varies from 30 to $100 \mathrm{pg} / \mathrm{ml}$ of serum. Usually values of less than $50 \mathrm{pg} / \mathrm{ml}$ of serum were arbitrarily considered as $50 \mathrm{pg}$ for statistical analysis. Non-specific binding was estimated in each assay for each subject and used in the calculation of the amount of immunologically active GIP in the unknown samples. The inter-assay variance was $12.6 \%$, the intra-assay variance $9 \cdot 1 \%$ (mean of 48 assays).

The GIP antiserum used did not cross-react with glucagon, secretin, CCK, and gastrin (Kuzio et al., 1974). However, as high serum glucagon levels under the experimental conditions could be expected, it was reinvestigated to see if added glucagon interfered in the assay with the antibody against GIP. Glucagon in a concentration up to $2 \mathrm{ng} / \mathrm{ml}$ did not displace bound GIP. However, if $1 \mathrm{ng} / \mathrm{ml}$ glucagon was incubated together with fresh serum for one hour at room temperature a substance appeared in the serum which reacted with the antibody against GIP, possibly representing a breakdown product of glucagon. The formation of this substance was markedly reduced by the addition of Trasylol or by cooling the serum samples. Therefore, blood samples were immediately placed on ice and centrifuged at $4^{\circ} \mathrm{C}$ within 45 minutes and frozen. Addition of glucagon to GIP-containing solutions did not alter the measured IR-GIP levels. Results are expressed as the mean \pm SEM. Student's $t$ test for paired values was performed to determine the significance of differences between controls in the absence and presence of glucagon.

\section{Results}

EFFECT OF GLUCAGON ON BASAL CONCENTRATIONS OF SERUM IR-GIP, IRG, IRI AND

GLUCOSE

The effect of intravenous glucagon infusion on fasting serum levels of glucose, gastrin, GIP, and insulin is shown in Fig. 1. The average basal value of GIP was $326 \pm 61 \mathrm{pg} / \mathrm{ml}(\mathrm{n}=6)$; after infusion of glucagon at a concentration of $50 \mathrm{ng} / \mathrm{kg} / \mathrm{min}$ the basal level dropped slightly but not significantly; whereas after increasing the glucagon infusion to $50 \mathrm{ng} / \mathrm{kg} / \mathrm{min}$ a significant decrease of GIP levels was observed reaching a nadir of $109 \mathrm{pg} \pm 39 \mathrm{pg} / \mathrm{ml}$ after 20 

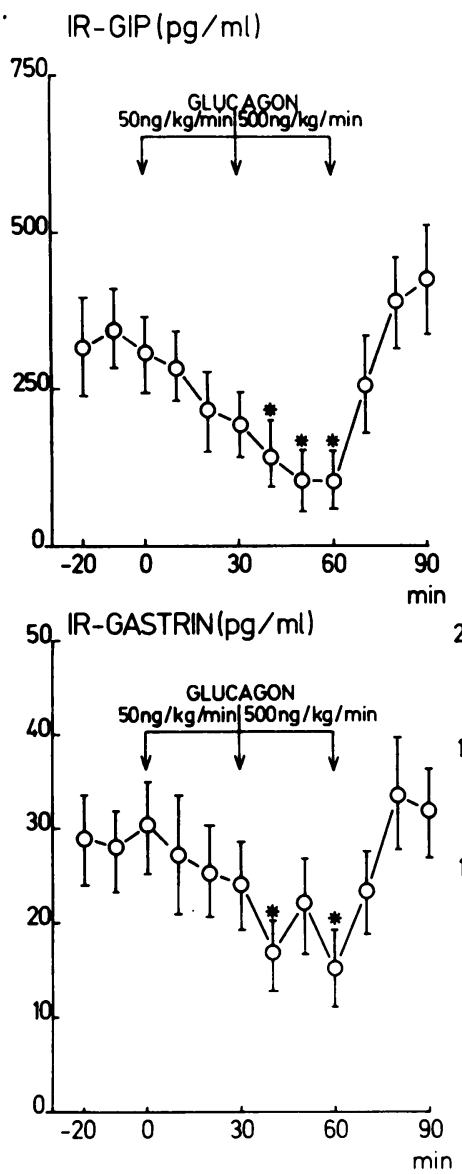

IR-INSULIN ( $\mu U / \mathrm{ml})$

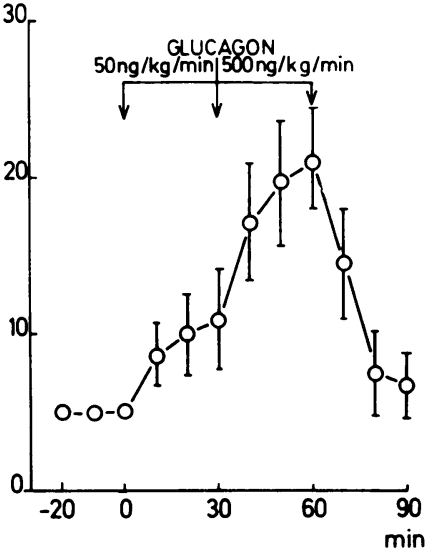

200 GLUCOSE (mg/100ml)

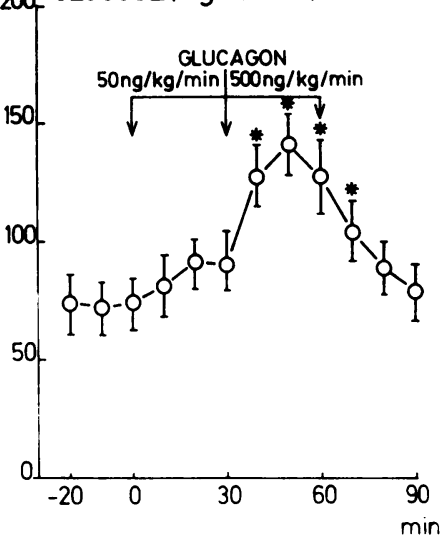

Fig. 1 Effect of glucagon $(50 \mathrm{ng} / \mathrm{kg} / \mathrm{min}$ from 0-30 min and $500 \mathrm{ng} / \mathrm{kg} / \mathrm{min}$ from 30-60 min) on serum levels of IR-GIP, $I R$-gastrin, IR-insulin, and blood glucose in six fasting healthy subjects. The vertical bars indicate SEM, asterisks significant differences from the pre-infusion values $(\mathbf{P}<0.05)$. minutes. GIP levels returned to basal values 10 minutes after the infusion was stopped.

Basal insulin levels were below the sensitivity of the assay ( $<6 \mu \mathrm{U} / \mathrm{ml}$ insulin) and increased during the glucagon infusion. Maximal insulin values were obtained 30 minutes after the infusion of $500 \mathrm{ng}$ glucagon $/ \mathrm{kg} / \mathrm{min}$ had started. Glucose increased only slightly at low glucagon concentrations, significantly higher blood glucose levels occurred during the infusion of $500 \mathrm{ng} / \mathrm{kg} / \mathrm{min}$ glucagon. The fall of serum gastrin in the presence of $50 \mathrm{ng} / \mathrm{kg} / \mathrm{min}$ glucagon was not significant; however, significant reduction of gastrin was seen during the higher glucagon dose.

Serum calcium decreased from $9.3 \mathrm{mg} / 100 \mathrm{ml} \pm$ 0.4 to $8.8 \mathrm{mg} / 100 \mathrm{ml} \pm 0.330 \mathrm{~min}$ after $50 \mathrm{ng} / \mathrm{kg} / \mathrm{min}$ glucagon. A further, significant drop to $8.2 \pm$ $0.3 \mathrm{mg} / 100 \mathrm{ml}(\mathrm{P}<0.05)$ occurred 20 minutes after the start of the higher glucagon infusion.
EFFECT OF GLUCAGON ON RESPONSE OF IR-GIP, IRG, IRI, AND GLUCOSE TO A TEST MEAL

The reproducibility of the hormonal response to the standard test meal was investigated in four subjects. To each subject the meal was given three times within two weeks. The maximal variation between the tests was as follows: serum IR-GIP $24 \%$, IR-insulin $27 \%$, IR-gastrin $21 \%$, and blood glucose $18 \%$. The effect of the glucagon infusion $(50 \mathrm{ng} / \mathrm{kg} / \mathrm{min})$ on the hormonal response to the test meal is demonstrated in Figs. 2 and 3. In protocol 1 the glucagon infusion was started 30 minutes before and continued until 90 minutes after ingestion of the test meal. The results are shown in Fig. 2. After onset of the glucagon infusion, basal levels of IR-GIP (278 \pm $64 \mathrm{pg} / \mathrm{ml}$ ) were slightly lowered; the sharp rise of serum levels of IR-GIP to $1051 \pm 306 \mathrm{pg} / \mathrm{ml}$ which occurred in the absence of glucagon was completely suppressed over the total period of the glucagon 

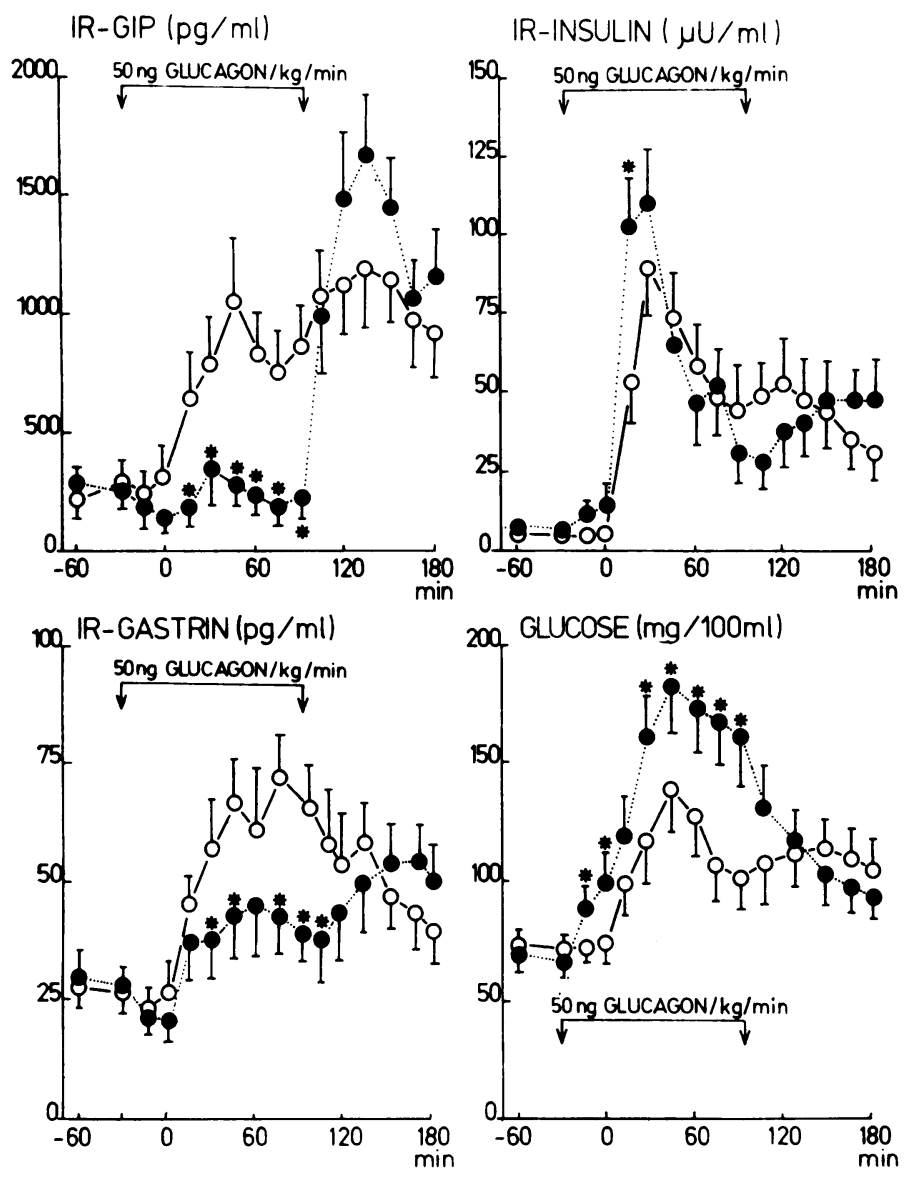

Fig. 2 Effect of glucagon $(50 \mathrm{ng} / \mathrm{kg} / \mathrm{min})$ on the response of IR-GIP, IR-gastrin, $I R$-insulin, and blood glucose to a mixed test meal in six healthy subjects. The test meal started at time 0 . The glucagon infusion started before the meal. $\mathrm{O}-\mathrm{O}=$ test meal alone. $\mathbf{0}-\mathbf{O}=$ test meal plus glucagon infusion. $\times=$ significant difference $(\mathrm{P}<0.05)$ from control experiment.

infusion. After stopping the infusion IR-GIP increased sharply in a rebound pattern to $1688 \pm$ $269 \mathrm{pg} / \mathrm{ml}$.

The IR-gastrin response to the test meal was significantly lower during the glucagon infusion but not completely abolished as in the case of the GIP response. Serum IR-G levels increased immediately after the end of the glucagon infusion. The serum glucose concentration was significantly higher than the control values for the total period of glucagon application. IRI levels were significantly increased by glucagon only in the fasting period and 15 minutes after ingestion of the test meal. At later times there was no significant difference between IRI levels in the presence or in the absence of glucagon.

As glucagon inhibits gastric motility (Necheles et al., 1966), delayed gastric emptying could be responsible for the inhibition of IR-GIP release by glucagon. Therefore in protocol 2 the glucagon infusion was started 60 minutes after ingestion of the test meal (Fig. 3). Again, IR-GIP levels dropped significantly after onset of the glucagon infusion and reaching the fasting values after 45 minutes. The IR-gastrin levels were also significantly reduced 30 minutes after the start of glucagon application. Serum glucose concentrations, on the other hand, increased during the infusion period significantly. The serum IRI values did not significantly differ from the control values during the glucagon application. They even tended to be lower than the controls at the time of the highest glucose levels.

\section{Discussion}

The data presented here demonstrate that exogenous glucagon lowers fasting IR-GIP levels (500 $\mathrm{ng} / \mathrm{kg} / \mathrm{min}$ ) and suppresses completely the IR-GIP response to a mixed high caloric test meal 

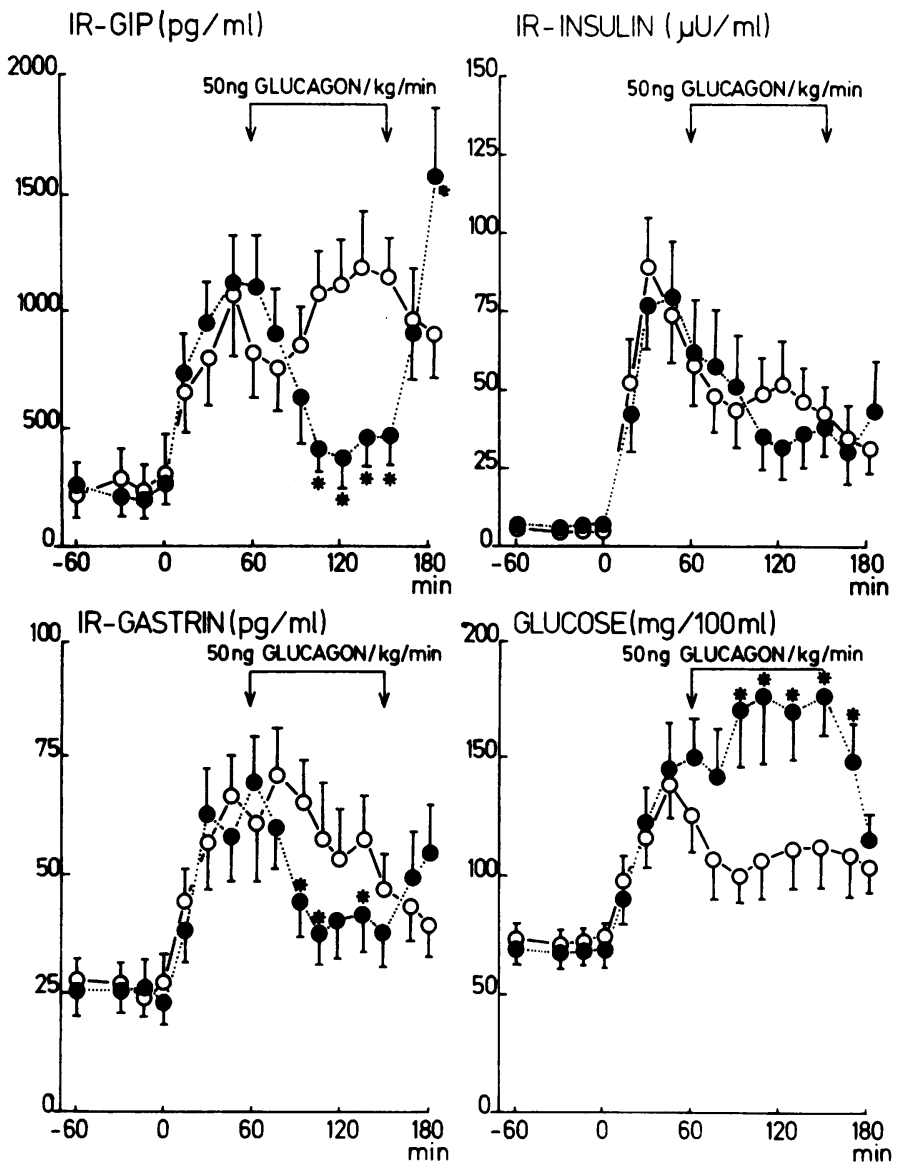

Fig. 3 Effect of glucagon $(50 \mathrm{ng} / \mathrm{kg} / \mathrm{mm})$ on meal stimulated IR-GIP, IR-gastrin, $I R$-insulin, and blood glucose in six healthy subjects. The test meal started at time 0. The glucagon infusion started 60 min after ingestion of the test meal. $\bigcirc-\bigcirc=$ test meal alone. $-1=$ test meal plus glucagon infusion. $\times=$ significant difference from control experiment $(\mathbf{P}<0.05)$.

( $50 \mathrm{ng} / \mathrm{kg} / \mathrm{min}$ ) in man. However, the findings do not yet indicate that endogenous glucagon participates in the physiological regulation of GIP release. The lower glucagon dose used is probably still $30-50$ times higher than the dose which is necessary to achieve glucagon plasma levels in the physiological range (Alford et al., 1974; Gerich et al., 1976).

The observed glucagon effect on IR-GIP levels closely resembles the suppressive effect of glucagon on fasting and meal stimulated serum gastrin levels (Becker et al., 1973; Hansky et al., 1973). The effect of glucagon on IR-gastrin has been confirmed in this study with even lower glucagon dosages. The significant suppression of fasting and meal stimulated serum IR-G levels occurred simultaneously with the suppression of IR-GIP values. Therefore, the glucagon effect could be mediated via gastrin if this hormone is normally involved in the release of GIP. However, this possibility can be ruled out because it has been shown that patients with undetectable serum IR-gastrin levels after gastroduodeno-pancreatectomy (Whipple's procedure) have an exaggerated IR-GIP response to a test meal (Creutzfeldt et al., 1976).

The following explanations for the lowering of IR-GIP levels by exogenous glucagon have to be discussed: (1) interference of high concentrations of glucagon with the radioimmunoassay for GIP, (2) promotion of destruction or excretion of GIP, (3) inhibition of GIP release.

The first possibility has been ruled out by in vitro addition of glucagon in concentrations up to $2 \mathrm{ng} / \mathrm{ml}$. No interference with the estimation of IR-GIP could be detected. The second possibility (promotion of destruction or excretion of GIP) cannot be discussed at the moment because nothing is yet known about the site of destruction and excretion of GIP. However, the kinetics of the fall of 
fasting and stimulated IR-GIP levels after the start of the glucagon infusion can be used as an argument against accelerated GIP excretion or destruction: glucagon induced a fall of the stimulated GIP levels of $50 \%$ within 30 minutes (Fig. 3). Also, in the fasting state the higher glucagon dose produced a fall of the serum IR-GIP level of $50 \%$ within 20 minutes (Fig. 1). This corresponds closely to the half-life time of exogenous GIP which has been reported to be 21 minutes (Brown et al., 1975).

The rapid fall of fasting and stimulated IR-GIP after the onset of the glucagon infusion suggests inhibition of GIP release by glucagon. This could be a direct effect on the GIP-producing cells of the gut or an interaction with mechanisms regulating or modulating the GIP release, such as motility, assimilation of food, or blood levels of glucose or insulin. Each of these factors is influenced by exogenous application of high doses of glucagon and could theoretically interfere with the GIP release. However, some of these mechanisms cannot explain the lowering of fasting IR-GIP levels because they are relevant only for GIP response to food.

Gastric and jejunal motility can be markedly inhibited by exogenous glucagon (Necheles et al., 1966; Hicks and Turnberg, 1974). Therefore, the test meal may not reach the GIP-producing cells in the duodenal and jejunal mucosa. This possibility has been excluded by the second experimental protocol: the glucagon infusion was started 60 minutes after the ingestion of the test meal-that is, after it had entered the gut and thus was in contact with the GIP-producing cells. Also under these conditions glucagon produced a sharp fall of the IR-GIP levels.

It has been demonstrated that exogenous glucagon inhibits glucose absorption (Gottesbüren et al., 1974). This may reduce the stimulus for GIP release because it has been suggested that the rate of absorption of nutrients is one of the facts which regulates GIP release (Brown et al., 1975; Creutzfeldt et al., 1976; Ebert et al., 1976a). However, glucose absorption is not completely inhibited even with pharmacological glucagon doses. Furthermore, this would not explain the glucagon effect on the fasting IR-GIP levels.

The main effect of glucagon is the induction of hyperglycaemia. It has been found that the GIP response to fat ingestion is decreased by a simultaneous intravenous infusion of glucose suggesting a negative feedback control for GIP mediated by glucose (Cleator and Gourlay, 1975; Crockett et al., 1976). As the blood glucose levels during the glucagon infusion were always higher than in the control period, these raised blood glucose levels could be the reason for the lowering effect of glucagon on serum IR-GIP. This argument is invalidated by the observation of normal or exaggerated IR-GIP response to a test meal in patients with pathological glucose tolerance (Creutzfeldt et al., 1976; Ebert et al., 1976a, b) -that is, in the presence of blood glucose levels far in excess of the values found in this study during the glucagon infusion.

Exogenous glucagon releases insulin (Samols et al., 1965). It has been suggested that insulin inhibits GIP release in the sense of a feedback control (Brown et al., 1975; Cleator and Gourlay, 1975; Crockett et al., 1976). Thus, high serum IRI levels might explain suppression of IR-GIP. However, the IRI increase during glucagon infusion was small only in the fasting state (Fig. 1) and not different from the control experiments after the test meal (Figs. 2 and 3 ). It is, therefore, not probable that endogenous insulin is involved in the suppressive effect of glucagon on serum IR-GIP. On the other hand, the similarity of the IRI response to the test meal with and without glucagon infusion demonstrates that pharmacological doses of glucagon (directly and/or via hyperglycaemia) can compensate for the abolished insulin-releasing potency of GIP.

The most probable mode of action of glucagon on GIP release seems to be a direct inhibition of secretion on the cellular level. As nothing is known about the stimulus secretion coupling of the GIP-producing cells the exact mechanism cannot yet be understood. As in the case of glucagon induced inhibition of gastrin release, glucagon induced changes of calcium metabolism and calcitonin secretion may be discussed (Becker et al., 1973). Also in this study the glucagon infusion significantly lowered serum calcium levels in the fasting state.

Further investigations have to explain why exogenous glucagon stimulates the release of insulin (Samols et al., 1965) and calcitonin (Bell et al., 1970) and inhibits the release of gastrin (Becker et al., 1973; Hansky et al., 1973) and GIP (this study). The chemical structure of gastrin and GIP is not related. It will be also of interest to know if exogenous glucagon paradoxically stimulates GIP release from GIP-producing tumours, as has been well documented for gastrin release from gastrinomas (Becker et al., 1973; Korman et al., 1973; Creutzfeldt et al., 1975). Finally, it has to be elucidated if physiological levels of glucagon influence GIP secretion and if endogenous glucagon participates in the regulation of GIP secretion as discussed recently (Ebert $e t$ al., 1976a).

This work was supported by the Deutsche Forschungsgemeinschaft, Bonn-Bad Godesberg, grant $\mathrm{Cr} 20 / 7$ (20/12). The authors are grateful to Dr John C. Brown for introduction to the radio- 
immunoassay for GIP and for the supply of antiserum and purified GIP. They also wish to thank Mrs K. Illmer, Miss E. Bothe, and Mrs B. Hillebrecht for their excellent technical assistance.

\section{References}

Alford, F. P., Bloom, S. R., Nabarro, J. D. N., Hall, R., Besser, G. M., Coy, D. H., Kastin, A. J., and Schally, A. V. (1974). Glucagon control of fasting glucose in man. Lancet, 2, 974-977.

Becker, H. D., Reeder, D. D., and Thompson, J. C. (1973). Effect of glucagon on circulating gastrin. Gastroenterology, 65, 28-35.

Bell, N. H., and Kimble, J. B. (1970). Effects of glucagon, dibutyryl cyclic $3{ }^{\prime}, 5^{\prime}$-adenosine monophosphate and theophylline on calcitonin secretion in vitro. Journal of Clinical Investigation, 49, 1368-1373.

Bloom, S. R. (1975). GIP in diabetes. (Abstract.) Diabetologia, $11,334$.

Botha, J. L., Vinik, A. I., and Brown, J. C. (1976). Gastric inhibitory polypeptide (GIP) in chronic pancreatitis. Journal of Clinical Endocrinology and Metabolism, 42, 791-797.

Brown, J. C., Dryburgh, J. R., Ross, S. A., and Dupré, J. (1975). Identification and actions of gastric inhibitory polypeptide. Recent Progress in Hormone Research, 31, 487-532.

Cataland, S., Crockett, S. E., Brown, J. C., and Mazzaferri, E. L. (1974). Gastric inhibitory polypeptide (GIP) stimulation by oral glucose in man. Journal of Clinical Endocrinology and Metabolism, 39, 223-228.

Cleator, I. G. M., and Gourlay, R. H. (1975). Release of immunoreactive gastric inhibitory polypeptide (IR-GIP) by oral ingestion of food substances. American Journal of Surgery, 130, 128-135.

Creutzfeldt, W., Arnold, R., Creutzfeldt, C., and Track, N. S. (1975). Pathomorphologic, biochemical, and diagnostic aspects of gastrinomas (Zollinger-Ellison syndrome). Human Pathology, 6, 47-76.

Creutzfeldt, W., Ebert, R., Arnold, R., Frerichs, H., and Brown, J. C. (1976). Gastric inhibitory polypeptide (GIP), gastrin and insulin: response to test meal in coeliac disease and after duodeno-pancreatectomy. Diabetologia, 12, 279-286.

Crockett, S. E., Cataland, S., Falko, J. M., and Mazzaferri, E. L. (1975). Gastric inhibitory polypeptide (GIP): responses to variable doses of oral glucose in normal subjects and abnormal responses to oral glucose in patients with adult onset diabetes mellitus (AODM). (Abstract.) Diabetes, 24, 413.

Crockett, S. E., Cataland, S., Falko, J. M., and Mazzaferri, E. L. (1976). The insulinotropic effect of endogenous gastric inhibitory polypeptide in normal subjects. Journal of Clinical Endocrinology and Metabolism, 42, 1098-1103.

Ebert, R., Creutzfeldt, W., Brown, J. C., Frerichs, H., and Arnold, R. (1976a). Response of gastric inhibitory poly- peptide (GIP) to test meal in chronic pancreatitisrelationship to endocrine and exocrine insufficiency. Diabetologia, 12, 609-612.

Ebert, R., Frerichs, H., and Creutzfeldt, W. (1976b). Serum gastric inhibitory polypeptide (GIP) response in patients with maturity onset diabetes and in juvenile diabetics. (Abstract.) Diabetologia, 12, 388.

Falko, J. M., Crockett, S. E., Cataland, S., and Mazzaferri, E. L. (1975). Gastric inhibitory polypeptide (GIP) stimulated by fat ingestion in man. Journal of Clinical Endocrinology and Metabolism, 41, 260-265.

Gerich, J. E., Lorenzi, M., Bier, D. M., Tsalikian, E., Schneider, V., Karam, J. H., and Forsham, P. H. (1976). Effects of physiologic levels of glucagon and growth hormone on human carbohydrate and lipid metabolism. Journal of Clinical Investigation, 57, 875-884.

Gottesbüren, H., Leising, H., Menge, H., Lorenz-Meyer, H., and Riecken, E. O. (1974). Einfluss von Glucagon auf die Glucose-, Wasser- und Elektrolytresorption des menschlichen Jejunums. Klinische Wochenschrift, 52, 926-929.

Hansky, J., Soveny, C., and Korman, M. G. (1971). Effect of secretin on serum gastrin as measured by immunoassay. Gastroenterology, 61, 62-68.

Hansky, J., Soveny, C., and Korman, M. G. (1973). The effect of glucagon on serum gastrin. I. Studies in normal subjects. Gut, 14, 457-458.

Hicks, T., and Turnberg, L. A. (1974). Influence of glucagon on the human jejunum. Gastroenterology, 67, 1114-1118.

Korman, M. G., Soveny, C., and Hansky, J. (1973). The effect of glucagon on serum gastrin. II. Studies in pernicious anaemia and the Zollinger-Ellison syndrome. Gut, 14, 459-461.

Kuzio, M., Dryburgh, J. R., Malloy, K. M., and Brown, J. C. (1974). Radioimmunoassay for gastric inhibitory polypeptide. Gastroenterology, 66, 357-364.

Mayer, G., Arnold, R., Feurle, G., Fuchs, K., Ketterer, H., Track, N. S., and Creutzfeldt, W. (1974). Influence of feeding and sham feeding upon serum gastrin and gastric acid secretion in control subjects and duodenal ulcer patients. Scandinavian Journal of Gastroenterology, 9, 703-710.

Melani, F., Ditschuneit, H., Bartelt, K. M., Friedrich, H., and Pfeiffer, E. F. (1965). Über die radioimmunologische Bestimmung von Insulin im Blut. Klinische Wochenschrift, 43, 1000-1007.

Necheles, H., Sporn, J., and Walker, L. (1966). Effect of glucagon on gastrointestinal motility. American Journal of Gastroenterology, 45, 34-39.

Samols, E., Marri, G., and Marks, V. (1965). Promotion of insulin secretion by glucagon. Lancet, 2, 415-416.

Thomas, F. B., Mazzaferri, E. L., Crockett, S. E., Mekhjian, H. S., Gruemer, H. D., and Cataland, S. (1976). Stimulation of secretion of gastric inhibitory polypeptide and insulin by intraduodenal amino acid perfusion. Gastroenterology, 70, 523-527.

Thompson, J. C., Reeder, D. D., Bunchman, H. H., Becker, H. D., and Brandt, E. N. Jr. (1972). Effect of secretin on circulating gastrin. Annals of Surgery, 176, 384-393. 